\title{
Rituximab Therapy for Adults with Nephrotic Syndromes: Standard Schedules or B Cell-Targeted Therapy?
}

\author{
Lucia Del Vecchio $^{1, *(\mathbb{D})}$, Marco Allinovi ${ }^{2}\left(\mathbb{D}\right.$, Paolo Rocco $^{3}(\mathbb{D})$ and Bruno Brando $^{4}(\mathbb{D}$ \\ 1 Department of Nephrology and Dialysis, Sant'Anna Hospital, ASST Lariana, 22042 Como, Italy \\ 2 Nephrology, Dialysis and Transplantation Unit, Careggi University Hospital, 50134 Florence, Italy; \\ marco.allinovi@gmail.com \\ 3 Department of Pharmaceutical Sciences, Università degli Studi di Milano, Via G. Colombo, \\ 71-20133 Milan, Italy; paolo.rocco@unimi.it \\ 4 Haematology Laboratory and Transfusion Centre, Legnano General Hospital (Milan), 20025 Milan, Italy; \\ bruno.brando@asst-ovestmi.it \\ * Correspondence: lucia.delvecchio@asst-lariana.it
}

Citation: Del Vecchio, L.; Allinovi, M.; Rocco, P.; Brando, B. Rituximab Therapy for Adults with Nephrotic Syndromes: Standard Schedules or B Cell-Targeted Therapy? J. Clin. Med. 2021, 10, 5847. https://doi.org/ $10.3390 / \mathrm{jcm} 10245847$

Academic Editor:

Giovambattista Capasso

Received: 5 November 2021

Accepted: 8 December 2021

Published: 13 December 2021

Publisher's Note: MDPI stays neutral with regard to jurisdictional claims in published maps and institutional affiliations.

Copyright: (c) 2021 by the authors. Licensee MDPI, Basel, Switzerland. This article is an open access article distributed under the terms and conditions of the Creative Commons Attribution (CC BY) license (https:/ / creativecommons.org/licenses/by/ $4.0 /)$.

\begin{abstract}
Rituximab is a chimeric anti-CD20 monoclonal antibody. It acts mainly through complementdependent cytotoxicity on B cells expressing the CD20 marker. In this review, we analyse the efficacy and possible pitfalls of rituximab to treat nephrotic syndromes by taking into account pharmacological considerations and CD19 marker testing utility. Despite the fact that the drug has been in use for years, efficacy and treatment schedules in adults with nephrotic syndrome are still a matter of debate. Clinical trials have proven the efficacy and safety of rituximab in idiopathic membranous nephropathy. Data from observational studies also showed the efficacy of rituximab in minimal change disease and focal segmental glomerulosclerosis. Rituximab use is now widely recommended by new Kidney Disease Improved Outcome (KDIGO) guidelines in membranous nephropathy and in frequent-relapsing, steroid-dependent minimal change disease or focal segmental glomerulosclerosis. However, rituximab response has a large interindividual variability. One reason could be that rituximab is lost in the urine at a higher extent in patients with nonselective nephrotic proteinuria, exposing patients to different rituximab plasma levels. Moreover, the association between CD19+ levels and clinical response or relapses is not always present, making the use of this marker in clinical practice complex. High resolution flow cytometry has increased the capability of detecting residual CD19+ B cells. Moreover, it can identify specific B-cell subsets (including IgG-switched memory B cells), which can repopulate at different rates. Its wider use could become a useful tool for better understanding reasons of rituximab failure or avoiding unnecessary retreatments.
\end{abstract}

Keywords: rituximab; nephrotic syndrome; membranous nephropathy; B lymphocyte; CD19; focal segmental glomerulosclerosis; high-resolution flow cytometry

\section{Introduction}

Starting from the mid-20th century, in parallel with the birth and development of modern nephrology, glomerulonephritis had received a systematic histopathological classification and the idea caught on that therapeutic choices should be based accordingly. In particular, the development of immunofluorescence techniques showed the presence of immunoglobulin and complement factors trapped inside the glomeruli, supporting the role of the immune system in the pathogenesis and use of immunosuppressive agents for their treatment [1]. In this context, humoral immunity and antibody-producing B lymphocytes are often involved. They also contribute to tissue injury by producing inflammatory cytokines and by presenting antigen to T lymphocytes [2].

In recent years, it has become clear that some glomerulonephritis are full-fledged autoimmune diseases. Accordingly, antibodies against the M-type phospholipase A2 receptor (PLA2R), a podocyte membrane glycoprotein, are detected in nearly 70 to $80 \%$ of 
patients with membranous nephropathy (MN) [3]; their titre is related to disease severity [4] and treatment response [5]. A small percentage of patients are found positive for antibodies targeting to another podocyte protein, the thrombospondin type- 1 domain-containing 7A (THSD7A) [6]. More recently, other autoantigens were described [7,8], adding further complexity to the understanding of the pathogenesis of $\mathrm{MN}$ and to its distinction in primary or secondary forms [7].

The pathogenetic mechanisms at the basis of minimal change disease (MCD) and focal segmental glomerulosclerosis (FSGS) are much less clear. Both diseases affect the podocyte but with a different clinical presentation and treatment response, with MCD often transitioning to FSGS over its course (especially in those who develop treatment resistance) [9]. They probably represent a disease spectrum of different morphologic manifestations and stages and overlapping etiologic factors, including genetic ones, all causing nephrotic or subnephrotic syndrome as a consequence of podocyte damage [9]. Both humoral and cellular immunity have been implicated in their pathogenesis with non-well defined circulating factors damaging podocytes [10,11].

Despite significant improvement in the understanding of the pathogenesis, the treatment of nephrotic syndrome has remained quite aspecific, with steroids and immunosuppressants given with different doses and schedules representing the most used methods. These treatments are effective in many cases. However, the use of high-dose steroids and immunosuppressants can be burdened by several side effects and toxicity. Moreover, a significant number of patients are treatment resistant and often progress to end-stage kidney failure.

\section{Rational and Mechanisms of Action of Rituximab}

Rituximab is a chimeric monoclonal antibody (MoAbs) that depletes B cells expressing the CD20 antigen. Structurally, the drug is made by the fusion between the binding regions of the original murine anti-human CD20 with human IgG1 heavy chain and human kappa light-chain constant regions [12].

CD20 is a calcium-dependent co-stimulatory receptor of B cells, expressed on the cell membrane in the central phase of B lymphocyte development [13]. The rationale for using rituximab in B-cell targeted protocols resides in the particular kinetics of expression of this CD20 during B cell maturation. When CD20+ effectors and memory B lymphocytes are depleted, the activation chain leading to allo- and auto-antibody production is blocked. By the same token, early B cell precursors are spared, ensuring the survival of immature cells able to regenerate new antigen-naïve B cells, at least initially devoid of pathogenic autoreactivity. Mature plasmacells are also spared, thus preserving long-term defensive antibody memory [14]. Moreover, the high level of expression of CD20 on B cell membrane (around 150,000 antigen copies per B cell) and the closeness of its relevant epitopes to the B cell surface favour a high concentration of $\mathrm{MoAb}$ on its target and the optimal development of a series of cytotoxic interactions [15].

The main mechanism of action of rituximab on B cells is complement-dependent cytotoxicity mediated by the Fc portion of the antibody [16]. When rituximab binds two adjacent CD20 molecules on B cell surface, a complex molecular interaction takes place, greatly increasing the affinity for complement fixation [17]. This structural model is the key for subsequent complement recruitment. Complement activation may also have a causative role also in infusion toxicity during rituximab treatment [18].

A second mechanism of action of rituximab is antibody-dependent cellular cytotoxicity by a variety of effector cells, including natural killer (NK) cells, granulocytes and macrophages [16]. NK cells and presumably complement factors could have a synergistic effect [19]. This could be of interest from a clinical point of view, since both parameters can be deficient in various clinical settings.

Finally, studies have suggested that rituximab can act directly on podocytes to stabilize the cytoskeleton and improve proteinuria through an apparent B-lymphocyte independent mechanism $[20,21]$. The fact that rituximab effects go beyond CD20+ lymphocyte depletion 
could be a possible explanation why in clinical practice the correlation between the number of CD20+ cells and disease activity is not perfect and that in some patients the treatment effect seems to persist even after CD20 count normalisation.

\section{Rituximab Therapy in Nephrotic Syndrome}

New KDIGO guidelines on glomerulonephritis suggests a wider use of rituximab in adult patients with nephrotic syndrome than what was recommended eight years ago, reflecting consistent changes in available evidence and clinical practice [22].

The higher degree of evidence on rituximab use is available for MN, as several randomised clinical trials have become available in recent years. The Prospective Randomized Multicentric Open Label Study to Evaluate Rituximab Treatment for Idiopathic Membranous Nephropathy (GEMRITUX) trial [23] compared two $375 \mathrm{mg} / \mathrm{m}^{2}$ rituximab infusions one week apart with no therapy in 75 patients and found that a higher number of patients receiving rituximab achieved complete or partial remission of proteinuria at six months (albeit the difference was not statistically significant). This went together with a higher number of patients experiencing anti-PLA2R antibodies depletion. However, after a longer observation period (median follow-up was 17 months), remission occurred in $64.9 \%$ of the patients treated with rituximab compared to only $34.2 \%$ in those treated with supportive therapy. Safety was comparable in the two groups.

In the Membranous Nephropathy Trial Of Rituximab (MENTOR) trial [24], 130 subjects were assigned either to rituximab (1000 $\mathrm{mg}$ on days 1 and 15$)$ or cyclosporine with a starting dose of $3.5 \mathrm{mg} / \mathrm{kg} /$ day then given for six to fourteen months depending on proteinuria response (tapered and discontinued over two months if remission was observed at six months).

In comparison to cyclosporine, rituximab obtained complete or partial remission in a higher percentage of patients at one year ( $52 \%$ vs. $62 \%, p=0.004$ for non-inferiority) and two years ( $20 \%$ vs. $60 \%, p<0.001$ for both non-inferiority and superiority). This went together with a better safety profile and a faster and larger decline in anti PLA2R titre (in those achieving remission) favouring rituximab. However, the big difference in remission at two years was partially influenced by proteinuria recurrence in some patients following cyclosporine discontinuation [25]. Moreover, the enrolment of patients with moderate CKD may have increased the number of side effects related to cyclosporine use [25].

Recently, a meta-analysis of 21 studies (603 patients) confirmed the efficacy of rituximab in $\mathrm{MN}$, showing an overall remission rate of $67 \%$ and a mean proteinuria decrease of $-4.90 \mathrm{~g} /$ day $(95 \% \mathrm{CI}-6.18,-3.63)$; rituximab efficacy was not significantly related to anti-PLA2R antibody status or previous immunosuppressive therapy [26].

The Sequential Treatment with Tacrolimus and Rituximab versus Alternating Corticosteroids and Cyclophosphamide in PMN study (STARMEN) compared treatment with corticosteroids and cyclophosphamide to a sequential regimen of tacrolimus $(0.05 \mathrm{mg} / \mathrm{Kg} /$ day for six months then decreased and stopped at month nine) and rituximab (1 $\mathrm{g}$ at months six). The rational of the combination is that the non-immunosuppressive effects of calcineurin inhibitors could be reinforced by rituximab and that the latter could prevent relapses at the time of calcineurin inhibitor decalage or interruption. The combination of steroids and cyclophosphamide showed superiority in comparison to tacrolimus plus rituximab in achieving complete or partial remission at 24 months ( $83.7 \%$ vs. $58.1 \%$, respectively; RR $1.44 ; 95 \%$ CI 1.08 to 1.92) [27]. The percentage of severe adverse events was comparable in the two groups (even if those randomized to the Ponticelli's regimen experienced more severe infections, more adverse events and more adverse events per patient).

The Rituximab versus Steroids and Cyclophosphamide in the Treatment of Idiopathic Membranous Nephropathy (RI-CYCLO) trial [28] compared two rituximab infusions (1 g) two weeks apart to a regimen with corticosteroids and cyclophosphamide. At 24 months, the probability of complete or partial remission was comparable in rituximab and cyclic regimen ( $85 \%$ vs. $81 \%$, respectively). The reduction of anti-PLA2R1 serum levels during follow-up occurred more rapidly in the rituximab arm and was accompanied by a decrease 
in proteinuria. The percentage of severe adverse events was comparable in the two groups (even if the patients randomized to rituximab experienced more drug infusion reactions).

Table 1 summarises the main efficacy and safety data of the GEMRITUX, MENTOR, STARMEN, and RI-CYCLO trials.

Table 1. Main efficacy and safety data of the GEMRITUX, MENTOR, and STARMEN trials in membranous nephropathy.

\begin{tabular}{|c|c|c|c|c|}
\hline CLINICAL TRIAL & GEMRITUX [23] & MENTOR [24] & STARMEN [27] & RI-CYCLO [28] \\
\hline Country & France & $\begin{array}{l}\text { The United States and } \\
\text { Canada }\end{array}$ & $\begin{array}{l}\text { Spain, France and the } \\
\text { Netherlands }\end{array}$ & Italy and Switzerland \\
\hline Publication Year & 2017 & 2019 & 2020 & 2021 \\
\hline Randomized patients $(n)$ & 75 & 130 & 86 & 74 \\
\hline Inclusion criteria & $\begin{array}{l}\text { Proteinuria } \\
\geq 3.5 \mathrm{~g} / \text { day or a } \\
\text { urinary } \\
\text { protein-to-creatinine } \\
\text { ratio } \geq 3500 \mathrm{mg} / \mathrm{g}, \\
\text { and serum albumin } \\
<30 \mathrm{~g} / \mathrm{L} \text { for at least } \\
6 \text { months with } \\
\text { maximal dose of } \\
\text { RAS blockade } \\
\text { eGFR }> \\
30 \mathrm{~mL} / \mathrm{min} / 1.73 \mathrm{~m}^{2}\end{array}$ & $\begin{array}{ll}\text { - } & \text { Proteinuria }> \\
& 5 \mathrm{~g} / \text { day on two } \\
& \text { samples } \\
& \text { Decline of }<50 \% \text { in } \\
\text { proteinuria despite } \\
\text { NIAT for at least } 3 \\
\text { months before } \\
\text { randomization } \\
\text { eGFR or creatinine } \\
\text { clearance } \\
>40 \mathrm{~mL} / \mathrm{min} / 1.73 \mathrm{~m}^{2}\end{array}$ & $\begin{array}{ll}-\quad & \text { Proteinuria }> \\
& 4 \mathrm{~g} / \text { day after } 6 \\
& \text { months of } \\
\text { observation } \\
\text { - } \quad \text { Hypoalbuminemia } \\
(\leq 3.5 \mathrm{~g} / \mathrm{dL}) \\
\text { eGFR } \\
\geq 45 \mathrm{~mL} / \mathrm{min} / 1.73 \mathrm{~m}^{2}\end{array}$ & $\begin{array}{l}\text { Proteinuria }> \\
\text { 3.5 g/day on three } \\
\text { 24-h urine } \\
\text { collections (once a } \\
\text { week for } 3 \text { weeks), } \\
\text { on RAS blockade } \\
\text { eGFR } \\
\geq 30 \mathrm{~mL} / \mathrm{min} / 1.73 \mathrm{~m}^{2}\end{array}$ \\
\hline Rituximab group & $\begin{array}{l}375 \mathrm{mg} / \mathrm{m}^{2} \text { on days } 1 \text { and } \\
8 \text { in association with NIAT }\end{array}$ & $\begin{array}{l}\text { - } \quad 1000 \text { mg on days } 1 \\
\text { and } 15 \\
\text { A second course } \\
\text { administered if } \\
\text { proteinuria was } \\
\text { reduced by at least } \\
25 \% \text { at } 6 \text { months but } \\
\text { no complete } \\
\text { remission } \\
\text { Continuing NIAT }\end{array}$ & $\begin{array}{l}\text { Oral tacrolimus } \\
\text { (0.05 mg/Kg/day), } \\
\text { to reach target blood } \\
\text { levels of } 5-7 \mathrm{ng} / \mathrm{mL} \text {, } \\
\text { for six months. At } \\
\text { day } 180, \text { rituximab } \\
(1 \mathrm{~g}) \text { and tacrolimus } \\
\text { dosage was reduced } \\
\text { by } 25 \% \text { per month, } \\
\text { with complete } \\
\text { withdrawal at the } \\
\text { end of month } 9\end{array}$ & $\begin{array}{l}1000 \mathrm{mg} \text { on days } 1 \\
\text { and } 15 \\
\text { - Continuing NIAT }\end{array}$ \\
\hline Control group & NIAT & $\begin{array}{l}\text { Cyclosporine with a } \\
\text { starting dose of } \\
3.5 \mathrm{mg} / \mathrm{kg} / \text { day. } \\
\text { Target trough blood } \\
\text { levels of } 125 \text { to } \\
175 \mathrm{ng} / \mathrm{mL} \\
\text { Tapering according } \\
\text { to remission status } \\
\text { at } 6 \text { months (total } \\
\text { treatment length } \\
\text { from } 6 \text { to } 14 \text { months) } \\
\text { - Continuing NIAT }\end{array}$ & $\begin{array}{l}1 \mathrm{~g} \times 3 \\
\text { methylprednisolone } \\
\text { at months } 1,3 \text { and } 5, \\
\text { then } 0.5 \mathrm{mg} / \mathrm{Kg} / \text { day } \\
\text { orally from day } 4 \text { to } \\
\text { 30). At months } 2,4 \\
\text { and } 6 \text {, oral } \\
\text { cyclophosphamide } \\
\text { adjusted for age and } \\
\text { renal function } \\
\text { (1.0-2.0 mg/Kg/day } \\
\text { for } 30 \text { days) }\end{array}$ & $\begin{array}{l}1 \mathrm{~g} \times 3 \\
\text { methylprednisolone } \\
\text { at months } 1,3 \text { and } 5 \text {, } \\
\text { then } 0.5 \mathrm{mg} / \mathrm{Kg} / \text { day } \\
\text { orally from day } 4 \text { to } \\
\text { 30). At months } 2,4 \\
\text { and } 6, \text { oral } \\
\text { cyclophosphamide } \\
(2.0 \mathrm{mg} / \mathrm{Kg} / \text { day for } \\
30 \text { days }) \\
\text { Continuing NIAT }\end{array}$ \\
\hline Baseline characteristics: & \multirow[b]{2}{*}{56} & & & \\
\hline - $\quad$ Mean Age (years) & & Around 52 & 55.7 & 55 \\
\hline - $\quad$ Body weight $(\mathrm{kg})$ & 76 & Around 90 & 78.5 & 76 \\
\hline $\begin{array}{l}\text { Protein-to- } \\
\text { creatinine ratio, } \\
\mathrm{mg} / \mathrm{g}\end{array}$ & 7363.2 (4702.9-9735.0) & NA & NA & NA \\
\hline Proteinuria (g/day) & NA & 8.9 (median) & 7.4 (median) & 6 \\
\hline - $\quad$ eGFR & 68.6 & NA & 79.8 & 84 \\
\hline $\begin{array}{l}\mathrm{CrCl} \\
\left(\mathrm{mL} / \mathrm{min} / 1.73 \mathrm{~m}^{2}\right)\end{array}$ & NA & Around 86 & NA & NA \\
\hline $\begin{array}{l}\text { Positive } \\
\text { Anti-PLAR2 (\%) }\end{array}$ & 73.3 & 73.8 & $77 \%$ & $66 \%$ \\
\hline
\end{tabular}


Table 1. Cont.

\begin{tabular}{|c|c|c|c|c|}
\hline CLINICAL TRIAL & GEMRITUX [23] & MENTOR [24] & STARMEN [27] & RI-CYCLO [28] \\
\hline Primary endpoint & $\begin{array}{l}\text { Complete or partial } \\
\text { remission of proteinuria at } \\
6 \text { months }\end{array}$ & $\begin{array}{l}\text { Complete or partial } \\
\text { remission of proteinuria at } \\
24 \text { months }\end{array}$ & $\begin{array}{l}\text { Complete or partial } \\
\text { remission of proteinuria at } \\
24 \text { months }\end{array}$ & $\begin{array}{l}\text { Complete or partial } \\
\text { remission of proteinuria at } \\
12 \text { months }\end{array}$ \\
\hline Primary outcome & $\begin{array}{l}n=13(35.1 \% ; 95 \%[95 \% \\
C I, 19.7 \text { to } 50.5) \text { in the } \\
\text { rituximab group and } n=8 \\
(21.1 \% ; 95 \% \text { CI, } 8.1 \text { to } 34.0) \\
\text { in the NIAT group; } \\
p=0.21\end{array}$ & $\begin{array}{l}n=39(60 \%) \text { in the } \\
\text { rituximab group and } \\
n=13(20 \%) \text { in the } \\
\text { cyclosporine group (risk } \\
\text { difference, } 40 \text { percentage } \\
\text { points; } 95 \% \text { CI, } 25 \text { to } 55 ; p \\
<0.001 \text { for both } \\
\text { non-inferiority and } \\
\text { superiority). }\end{array}$ & $\begin{array}{l}n=36(83.7 \%) \text { in the } \\
\text { corticosteroid- } \\
\text { cyclophosphamide group } \\
\text { and } n=25(58.1 \%) \text { in the } \\
\text { tacrolimus-rituximab } \\
\text { group (RR } 1.44 ; 95 \% \text { CI } \\
1.08 \text { to } 1.92)\end{array}$ & $\begin{array}{l}n=23(62 \%) \text { in the } \\
\text { rituximab group and } \\
n=27(73 \%) \text { receiving the } \\
\text { cyclic regimen }(\mathrm{OR}, 0.61 ; \\
95 \% \mathrm{CI}, 0.23 \text { to } 1.63) .\end{array}$ \\
\hline Anti-PLA2R-Ab trend & $\begin{array}{l}\text { At } 6 \text { months deletion in } 13 \\
\text { of } 26(50 \%) \text { in the } \\
\text { rituximab group and } 3 \text { out } \\
\text { of } 25(12 \%) \text { in NIAT group } \\
(p=0.004)\end{array}$ & $\begin{array}{l}\text { In the subgroup achieving } \\
\text { partial or complete } \\
\text { remission higher } \\
\text { reduction of anti PLAR2 } \\
\text { ab titre for rituximab } \\
\text { group in comparison to } \\
\text { cyclosporine at all-time } \\
\text { points }\end{array}$ & $\begin{array}{l}\text { Significant decrease in } \\
\text { both treatment groups. A } \\
\text { higher proportion of } \\
\text { anti-PLA2R-positive } \\
\text { patients achieved } \\
\text { immunological response } \\
\text { at } 3 \text { and } 6 \text { months in the } \\
\text { corticosteroid- } \\
\text { cyclophosphamide group } \\
\text { (77\% and } 92 \% \text {, } \\
\text { respectively), as compared } \\
\text { to the } \\
\text { tacrolimus-rituximab } \\
\text { group ( } 45 \% \text { and } 70 \%, \\
\text { respectively) }\end{array}$ & $\begin{array}{l}\text { Anti-PLA2R levels } \\
\text { decreased in both arms } \\
\text { during follow-up, more } \\
\text { rapidly in the rituximab } \\
\text { arm. }\end{array}$ \\
\hline Safety & $\begin{array}{l}\text { Eight }(21 \%) \text { serious } \\
\text { adverse events in each } \\
\text { group }\end{array}$ & $\begin{array}{l}\text { Serious adverse events in } \\
11 \text { patients }(17 \%) \text { in the } \\
\text { rituximab group and in } 20 \\
(31 \%) \text { in the cyclosporine } \\
\text { group ( } p=0.06)\end{array}$ & $\begin{array}{l}\text { More adverse events and } \\
\text { more adverse events per } \\
\text { patient in the } \\
\text { corticosteroids- } \\
\text { cyclophosphamide group } \\
\text { than in the } \\
\text { tacrolimus-rituximab } \\
\text { group }(p=0.04) .\end{array}$ & $\begin{array}{l}\text { Serious adverse events } \\
\text { occurred in } 19 \% \text { of } \\
\text { patients receiving } \\
\text { rituximab and in } 14 \% \\
\text { receiving SOFIJA } \\
\text { the cyclic regimen. }\end{array}$ \\
\hline
\end{tabular}

Legend: GEMRITUX, Evaluate Rituximab Treatment for Idiopathic Membranous Nephropathy; MENTOR, Evaluate Rituximab Treatment for Idiopathic Membranous Nephropathy; RAS, Renin Angiotensin System; NIAT, non-immunosuppressive antiproteinuric treatment; eGFR, estimated glomerular filtration rate; $\mathrm{CrCl}$, creatinine clearance; Anti-PLA2R-Ab, antiphospholipase A2 receptor antibody; RI-CYCLO, Rituximab versus Steroids and Cyclophosphamide in the Treatment of Idiopathic Membranous Nephropathy; STARMEN, Sequential Treatment with Tacrolimus and Rituximab versus Alternating Corticosteroids and Cyclophosphamide in PMN study.

Recently, another study compared low-dose rituximab (a single dose of $375 \mathrm{mg} / \mathrm{m}^{2}$ ), a standard rituximab protocol (four weekly doses of $375 \mathrm{mg} / \mathrm{m}^{2}$ ) with Ponticelli's regimen (cyclic regimen with corticosteroids and cyclophosphamide) [29], obtaining similar data to those of the RI-CYCLO study [28].

According to the 2021 KIDIGO guidelines [22], rituximab should be offered as initial treatment to $\mathrm{MN}$ patients at moderate or high risk, whereas the Ponticelli's regimen should be considered for those at very high risk of progression (1B). Rituximab is also recommended as a therapeutic option at first recurrence or when anti PLA2R antibodies did not become negative after six months. Either the rheumatological schedule $(1 \mathrm{~g}$ given two weeks apart) or the classical weekly $375 \mathrm{mg} / \mathrm{m}^{2}$ dose for four weeks can be chosen as a dose.

Several case series and retrospective studies suggest the efficacy and safety of rituximab also in MCD and FSGS [30-33]. In particular, rituximab seems particularly useful in the subset of patients who are steroid- or calcineurin- dependent. In 2014, the Rituximab in Nephrotic Syndrome of Steroid-Dependent or Frequently Relapsing Minimal Change Disease or Focal Segmental Glomerulosclerosis (NEMO) Study [34] reported a decrease in the relapse rate in a cohort of 30 patients with steroid-dependent or frequently relapsing nephrotic syndrome in remission at the time of treatment with rituximab (a single $375 \mathrm{mg} / \mathrm{m}^{2}$ dose in most cases). Conversely, rituximab was found of little use in an Italian 
cohort of 8 FSGS patients who had biopsy-proven FSGS with contraindications to corticosteroids or conventional immunosuppression [35]. These opposing efficacy data could be partially due to an insufficient characterization of the different FSGS forms (primary, secondary or genetic). In this regard, segmental versus diffuse foot process effacement or disease onset with either full-blown nephrotic syndrome or sub-nephrotic proteinuria could be of help in identifying the patients on whom insisting with immunosuppression therapy [36]. Recently, a meta-analysis of 16 observational studies on either FSGS or MCD seemed to support the efficacy of rituximab in these nephropathies; as expected, patients with MCD achieved remission in higher percentage in comparison to those with FSGS [37].

In recent years, some randomised, clinical trials provided further evidence on the efficacy and safety of rituximab in children with steroid-resistant or steroid-dependent nephrotic syndrome compared to placebo [38], steroids [39,40] or calcineurin inhibitors [40, 41].

As for MN, new KDIGO guidelines suggest a wider use of rituximab in patients with MCD or FSGS [22]. In MCD, rituximab can be used as initial therapy in those patients who have contraindications to glucocorticoids or better in those who are frequent relapsing or steroid dependent.

\section{Pitfalls and Open Issues of Rituximab Therapy in Nephrotic Syndrome}

Even if rituximab is an effective treatment for $\mathrm{MN}$, a significant percentage of patients do not achieve a satisfactory decrease of proteinuria. Several reasons have been hypothesised to explain treatment failure in $\mathrm{MN}$, in general or more specifically in those receiving rituximab.

First of all, available evidence for rituximab use comes from trials testing different treatment schedule and doses. Probably the higher the dose, the better the results, as testified by the finding of the MENTOR trial in MN [24]. However, lower doses have not been tested properly by long-term randomized clinical trials. Indeed, in the GEMRITUX trial [23], the primary endpoint was evaluated only at six months and the patients were treated with two doses of $375 \mathrm{mg} / \mathrm{m}^{2}$ each.

Patients with high titres of baseline anti-PLAR2 antibody are more resistant to treatment [42-44]. In this subset of patients, rituximab efficacy can be improved by a second course of treatment [45]. Similarly, high titres of anti-SOD2 and anti- $\alpha$-enolase antibodies at diagnosis were associated with poor clinical outcome, with patients having combined positivity showing the poorest one [8]. PLA2R1 epitope spreading has been reported as another marker of poor outcome and treatment failure (even if this has been recently contradicted) $[8,46]$. In the future, the serological classification could better characterise the patients and possibly personalise treatment schedules accordingly [47].

The development of neutralising anti-rituximab antibodies has also been described and is probably underestimated in clinical practice [48].

Also in MCD and FSGS, several open questions are pending on rituximab doses and schedules. Some studies showed remission of proteinuria with lower total rituximab doses, questioning the benefit of additional dosing [49-51]. However, in children with SSNS, a higher rate of relapse and a shorter time to first relapse have been described in those who received lower doses of rituximab [52-54]. These data may support that rituximab is characterised by a dose-dependent efficacy.

\section{The Nephrotic Syndrome and Rituximab Plasma Levels}

The administration schedules of rituximab for nephrotic syndrome were borrowed from those in use for non-Hodgkin's lymphoma (NHL) or autoimmune diseases. However, in nephrotic patients, the pharmacokinetics profile of rituximab can be different in comparison to other treatment indications, as the degree of proteinuria may have a significant effect on rituximab levels. Indeed, patients with $\mathrm{MN}$ have significantly lower rituximab serum concentrations in comparison to subjects with rheumatoid arthritis [55] or myasthenia gravis with no proteinuria [48], while receiving the same rituximab schedule. Interestingly, 
rituximab concentrations were higher at retreatments, possibly as a consequence of an improvement of the nephrotic syndrome. In patients with $\mathrm{MN}$ and nephrotic syndrome, rituximab also has a much shorter half-life in comparison to that observed in subjects with myasthenia gravis [48], NHL or rheumatoid arthritis [56].

It has been hypothesised that rituximab could be lost in the urine at a higher extent following a loss in the selectivity of the glomerular membrane (as it is the case in many forms of nephrotic syndrome) $[33,57,58]$; the urinary loss of rituximab in nephrotic syndrome may cause insufficient drug exposure and shorter serum drug half-life. In severe cases, rituximab half-life could be extremely reduced (less than one day), also because of pleural and peritoneal fluid loss $[57,59]$. It is then possible that poor results in children with steroid-resistant nephrotic syndrome may partially be due to insufficient rituximab plasma levels [51,53].

Consistently, MN patients treated with higher rituximab doses have higher serum levels, lower CD19+ counts and lower level of anti-PLA2R1 antibodies at six months [60]. However, serum rituximab levels in the 15 days following rituximab infusion did not differ significantly between responders and non-responders [55]. However, low residual rituximab levels at month 3 were shown to be correlated with poor B-cell depletion at months 3 and 6, with high anti-PLA2R1 titre at months 3,6, and 12, and with proteinuria at months 3,6 and 12 [48].

\section{The Correlation between CD19+ Depletion and Treatment Response}

CD19+ B-cell depletion occurs fast (within few hours) and almost all patients achieve it, even after receiving small doses when the infusion of the drug is stopped prematurely due to side effects (personal experience). At three months, circulating CD19+ B cells start to recover, but at six months most patients still have counts below the reference range. Afterwards, CD19+ lymphocytes progressively re-emerge into the circulation from month six to the end of the first year, usually returning to pre-treatment levels within twelve months (even if some patients maintain reduced CD19+ levels for much longer periods). However, the repopulation rate is extremely variable, depending on rituximab doses, underlying disease, previous immunosuppression and individual factors [61,62]. For instance, the repopulation rate seems to be longer in patients with systemic vasculitis [63] compared to those affected by rheumatoid arthritis [64]. On the contrary, it seems to be shorter in patients with systemic lupus erythematosus [65].

Some authors reported that the achievement and duration of clinical remission correlate well with CD19+ cell in MCD-FSGS [66,67] and MN [68,69]. Conversely, relapses are often preceded by B-cell repopulation. This has been well described in children with steroid-dependent (SDNS) and frequent-relapsing (FRNS) nephrotic syndrome [53,70-72]. Accordingly, a "CD19-targeted therapy" has been proposed to avoid unnecessary additional infusions or prevent relapses when needed. In this respect, Ramachandran et al. [73] reported their clinical experience on $109 \mathrm{MN}$ patients who were treated with three different dosing regimens $\left(375 \mathrm{mg} / \mathrm{m}^{2}\right.$ weekly for four weeks, $1 \mathrm{~g}$ on days 0 and 15 and CD19-guided rituximab therapy. No difference was found in the response rate to the different rituximab schedules, but the patients receiving the CD19-guided scheduled regimen needed a lower rituximab dose and possibly had a better safety profile. Good results were obtained also in 53 adults with MCD/FSGS with SDNS, FRNS and steroid-resistant nephrotic syndrome who received CD19-targeted rituximab while in remission [74]. Most of the patients maintained a sustained remission over a median follow-up of 36 months allowing the withdrawal of calcineurin inhibitors and steroids in nearly $80 \%$ of the cases. The mean total dose of rituximab at one year was $788.7 \pm 128.1 \mathrm{mg}$.

Unfortunately, this approach is limited by the fact that the correlation between CD19+ levels and the response to treatment is weak in many instances. Indeed, despite complete peripheral CD19+ B-cell depletion, not all the patients have a clinical response to rituximab [23,75-77]. On the contrary, some patients who do not achieve B-cell depletion have an improvement in proteinuria $[51,78,79]$. Relapses during a full B-cell depletion have 
been also described $[33,80,81]$. Finally, some treated patients maintain long-term clinical remission even after total B-cell recovery $[53,70,72,82,83]$.

Even if B-cell depletion is easy to achieve with low-dose rituximab, insufficient dosing may delay remission [56] or expose the patient to a higher rate of relapse and to a shorter time to the first relapse compared to patients receiving higher doses [66,82].

Altogether, CD19+ count alone may not be sufficient alone for driving optimal dosing and administration schedule of rituximab in relation to the single patient needs and clinical course.

In recent years, the concept is emerging that other cellular biomarkers could be more accurate than the mere CD19+ count. In particular, memory B cells could escape rituximab-mediated depletion or repopulate earlier, thus favouring relapses. Memory B cells expressing the immunoglobulin-G (IgG)-switched phenotype are irreversibly committed to plasma cell differentiation and are considered as the reservoir of potential pathogenic autoantibodies, as opposed to $\operatorname{IgD/IgM~memory~and~naïve~B~cells.~Long-lived~plasma-~}$ cells lose the CD20 surface antigen, are refractory to conventional immunosuppression, including rituximab and hard to eliminate [84].

Moreover, traditional flow cytometric (FCM) analyses may lack of sufficient sensitivity to detect very low CD19+ count level that could burst or maintain active immunological activity.

\section{High-Sensitivity Flow Cytometric Cell Counting for Immune Monitoring of Anti-CD20 Therapies}

In the last decade, the measurement of B cell levels and their functional subsets has been greatly influenced by the technical evolution of FCM techniques. In particular, the availability of high-sensitivity, multi-colour, FCM techniques has made possible the precise detection and count of extremely low levels of $B$ cells and $B$ cell subsets in the peripheral blood of patients receiving anti-CD20 MoAbs $[14,85,86]$.

A standardised and easily applicable FCM immune monitoring protocol (ISCCA Protocol) has been recently developed to accomplish this task [85]. A number of technical requirements are needed to ensure a precise and reproducible analysis: (i) a high-resolution technique including at least one million leucocytes (the more, the better) to allow the acquisition of a sufficient number of $B$ cells and their small subsets which can be greatly reduced under treatment; (ii) a multi-colour FCM technique using 8 fluorescence channels and 10 cellular markers [86]; (iii) a timing scheme that includes serial measurements at pre-defined timepoints during the patients' follow-up to adjust the therapy protocol on an individual basis. An example of a simplified analysis protocol is depicted in Figure 1.

A simplified gating strategy in a healthy subject with the acquisition of about 1,126,000 leukocyte events is represented. In each diagram the axes labels indicate the respective cell surface markers and fluorochrome types, as described in detail in the reference by Gatti et al., 2020 [86]. Lymphocytes are captured and divided into T, B, and NK cells. B cells are cleaned from contaminants and divided into CD19+ CD27- naïve and CD19+ CD27+ memory cells. Memory B cells are further dissected into surface IgG-switched and IgM memory cells. T cells are divided into the CD4+ and CD8+ subsets. The table reports the relevant cell event numbers and the percentages of each cell subsets with reference to the respective parent population, to be included in the clinical report.

The ISCCA Protocol includes the simultaneous enumeration of T-cell subsets and NK lymphocytes. This is of importance since some anti-CD20 MoAbs are dependent from the availability of functional Fc-gamma receptors on NK cells [87]. Moreover, a relatively preserved $\mathrm{T}$ cell and Treg repertoire is a prerequisite to prevent excess immunosuppression after anti-CD20 treatments and possibly to cooperate in the cytotoxic mechanisms $[87,88]$. 


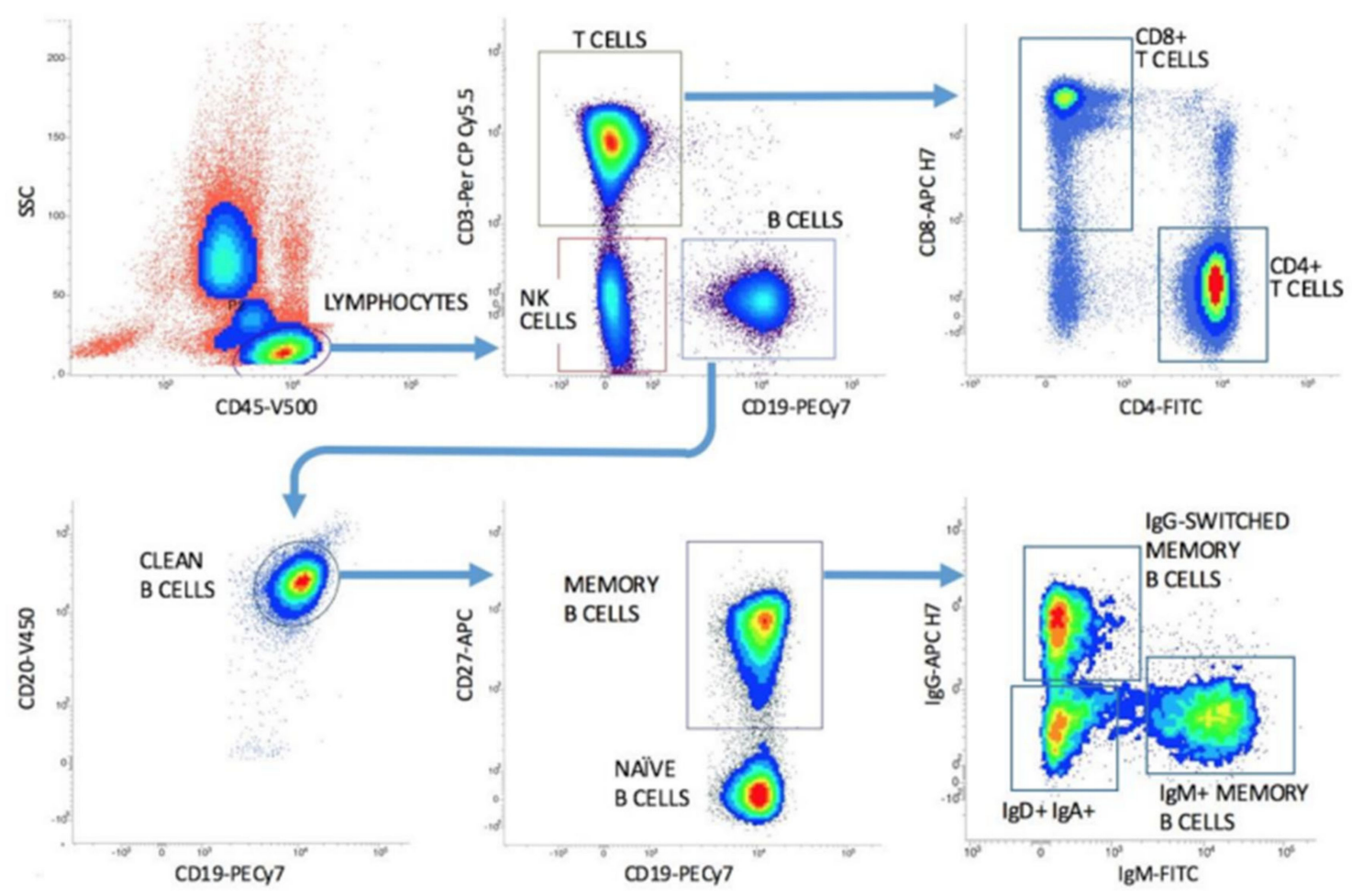

Figure 1. The ISCCA Protocol for the high-resolution analysis of functional B cell subsets.

Another important feature of the ISCCA Protocol is the further subsetting of CD19+ CD27+ memory B cells into surface IgG+ (committed memory Ig-switched) and IgM+ (relatively immature memory B) cells. This provides a deeper insight of the functional status of the memory B cell response, since the IgG switch represents a point of no return in B cell activation. The latter point has proved valuable in dissecting patients with rheumatoid arthritis with different responses to therapy [14,86] and could be applied in other immune-mediated disorders, including autoimmune renal diseases (Figure 2).

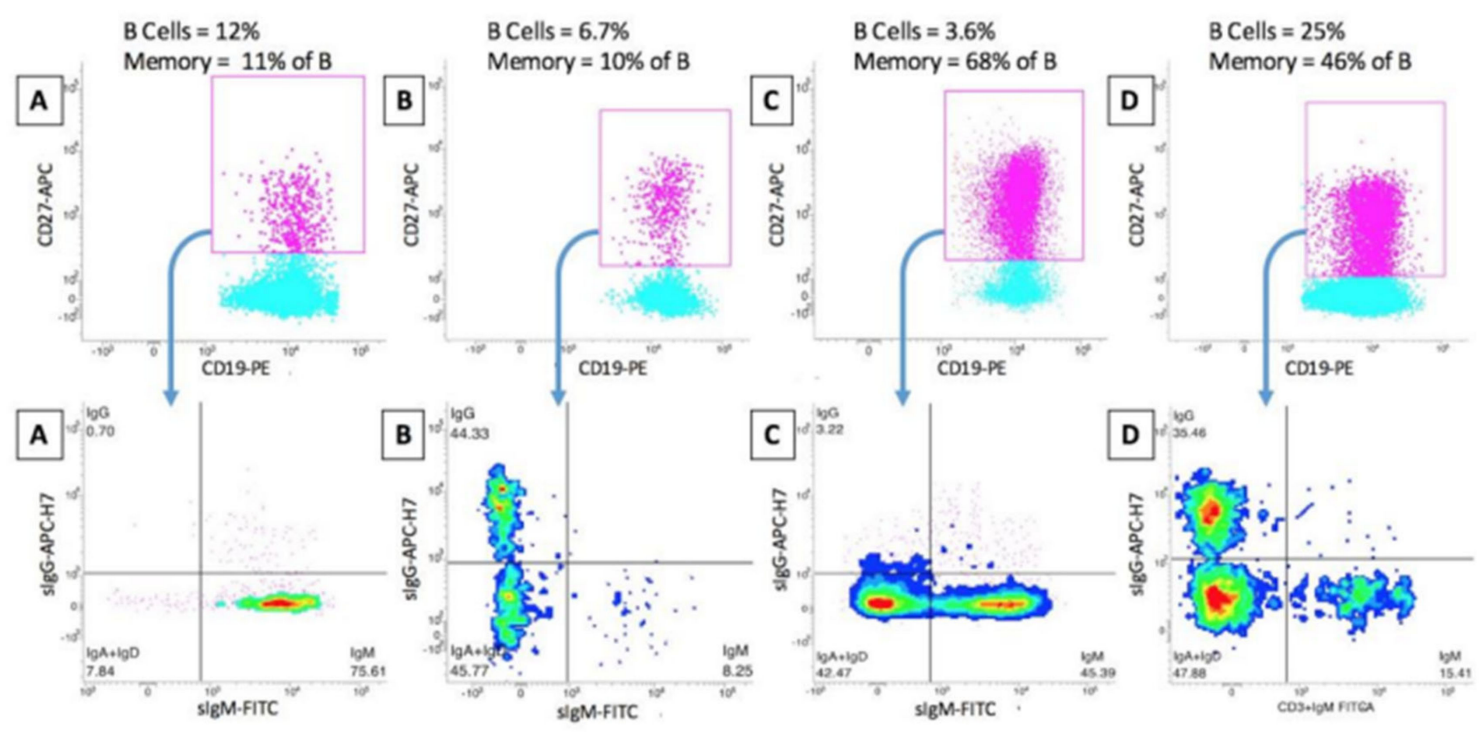

Figure 2. The functional heterogeneity of CD19+ CD27+ memory B.

Marked differences in the relative proportions of IgG-switched and IgM memory B cells can be present in different patients and can be associated with various degrees of 
disease activity and response to therapy. This indicates that the evaluation of the mere percentage of memory B cells is not informative enough in clinical immune monitoring. Four representative cases of patients with autoimmune disorders are depicted (in columns A, B, C and D, respectively), with opposite IgG/IgM distributions, despite similar levels of total memory B cells.

\section{High-Sensitivity Flow Cytometric Cell Counting in Clinical Practice}

A wider use of quantitative monitoring protocols may provide clinicians with additional information to evaluate the clinical response and better calibrate immunosuppression in the single patient, especially when nephrotic proteinuria acts as a confounding factor.

In most of the patients, an operational B cell 'disappearance' (i.e., $<0.01 / \mu \mathrm{L}$ by highresolution FCM) is obtained after the first rituximab dose, and may last up to 8-10 months. Besides, the repopulation of as few as $0.5 \mathrm{~B}$ cells $/ \mu \mathrm{L}$ can be considered as an indicator that the effect of rituximab is wearing off. Looking at B cell subsets, sustained depletion of CD27+ memory B cells and the reappearance of naïve B cells are more precise indicators of clinical response $[79,89,90]$. In particular, the repopulation of an unbalanced B cell repertoire, with an excess of CD19+ CD27+ memory B cells and a lower proportion of CD19+ CD27- naïve B cells are considered as an indicator of impending relapse [14].

The kinetics of B-cell repopulation was analysed in one patient with $\mathrm{MN}$ by means of using fluorescence-activated cell sorter analysis [91]. Rituximab rapidly induced complete disappearance of CD19+ B cells, plasmablasts, and memory B cells. Despite persistence of CD19+ depletion, plasmablasts and memory B cells re-emerged early before naive B cells.

More recently, it has become possible to directly delete surface IgG and IgM expression and thus to identify IgG-switched CD19+ CD27+ cells. This is a particular subset of memory $B$ cells that represents the earliest population potentially endowed with the pathogenic autoantibody memory [92].

\section{New Anti-CD20 Targeted Therapies for Nephrotic Syndrome}

A great deal of evidence has been accumulated over the last decade on the use of newly developed anti-B cell treatments in autoimmune disorders, such as ocrelizumab, ofatumumab and obinutuzumab, each endowed with different potency, a different balance of the respective cytotoxic mechanisms, and half-lives [93,94]. Despite belonging to the same pharmaceutical class and hitting the same cell target than rituximab, the new antiCD20 MoAbs should be considered as different drugs in many respects [94]. Given their different mechanism of action on B-cell depletion and being fully humanised, they possibly overcome resistance or immunogenicity towards rituximab.

Ofatumumab recognizes an epitope encompassing both the small and large extracellular loops of the CD20 antigen. It has been shown to be effective in rituximab-resistant nephrotic syndrome [95]. Moreover, it brings a faster depletion of anti-PLA2R antibody when associated with double-filtration plasmapheresis [96]. Recently, Ravani et al. [97] showed similar efficacy and safety of ofatumumab in comparison to rituximab in 140 children and young adults (aged 2-24 years) with nephrotic syndrome maintained in remission with prednisone and calcineurin inhibitors. Unfortunately, the marketing authorization of ofatumumab was withdrawn in the European Union for commercial reasons.

Obinutuzumab is the first recombinant IgG1 type-II anti-CD20 monoclonal antibody with Fc engineered to optimize the interaction with cellular Fc- $\gamma$ Receptor III-A. This change makes obinutuzumab more efficient in antibody-dependent cellular cytotoxicity (ADCC), in opsonic phagocytosis, and in inducing direct apoptosis of the cell target, as compared with rituximab $[93,94]$. Obinutuzumab also recognizes a CD20 epitope different from that of rituximab and was proven effective in rituximab-resistant haematological malignancies [94]. Anecdotally, it was found effective in the case of membranoproliferative glomerulonephritis secondary to CLL [98]. Recently, the Mayo Clinic Group described successful treatment with obinutuzumab of three cases of treatment-resistant MN [99]. 
Ocrelizumab is a humanized B cell depleting antibody, approved for treatment of multiple sclerosis (MS) [100]. As compared to rituximab, it displays an increased ADCC and a reduced complement-dependent cytotoxicity, while showing a longer half-life. Recently, a patient with MS and PLA2R-associated MN was successfully treated with this drug [101].

\section{Future Developments}

Anti-CD20 therapies have become an important treatment strategy of several glomerulonephritis. With increasing use, a wide patient- and disease-related variability of the clinical response to treatment has emerged. Although the use of high-dose rituximab protocols may obtain good clinical responses, one must pay a high price in terms of side effects and associated morbidity (especially in aged patients). On the contrary, some patients would need much lower doses to obtain remission and avoid relapses and are treated unnecessarily with high doses and/or repeated treatments.

Anti-CD20 therapies are a unique opportunity to directly measure the net immunosuppressive effect on the relevant cell target, to monitor the occurrence of escape or resistance phenomena, and to evaluate the timing and the cell composition of the post-treatment $\mathrm{B}$ cell recovery. In this context, the use of new objective biomarkers could help in tailoring the therapeutic regimens on each patient's clinical features (especially to avoid over-immunosuppression).

However, recent studies have shown that following anti-CD20 treatment other lymphocyte functional mechanisms may further play a role, thus making the interpretation of the biological findings more complex and sometimes controversial. Evidence is becoming available that the spleen can be a sanctuary where rituximab-resistant memory B cells with a peculiar phenotype and autoreactive plasma cells may settle [102]. Atypical 'doublenegative' memory B cells expressing the CD19+ CD27- sIgD- sIgG+ phenotype have been demonstrated and hypostasised to be the real precursors of pathogenic autoantibodies [103]. Double-negative memory B cells are also partly overlapped with CD19+ CD21CD11c+ Tbet+ Age-related B cells that accumulate during inflammaging. Rituximab also affects $\mathrm{T}$ cell and myeloid cell functions, while repopulating naïve $\mathrm{B}$ cells appear with a more activated phenotype, as compared to their pre-rituximab baseline counterparts [104].

The more in-depth immune system cells are studied, the wider the heterogeneity of functional cell subset and response or regulatory mechanisms is evidenced, thus necessitating a continuous upgrade of our knowledge and diagnostic panoply.

Author Contributions: Conceptualization, L.D.V., M.A., and B.B.; methodology, L.D.V., M.A., P.R., and B.B.; formal analysis, not applicable; investigation, L.D.V., M.A., P.R., and B.B.; data curation, not applicable.; writing-original draft preparation, L.D.V., M.A., P.R., and B.B.; writing-review and editing, L.D.V., M.A., P.R., and B.B.; supervision, L.D.V., M.A., P.R., and B.B.; and project administration, L.D.V., M.A., P.R., and B.B. All authors have read and agreed to the published version of the manuscript.

Funding: This research received no external funding.

Institutional Review Board Statement: This study was conducted according to the guidelines of the Declaration of Helsinki. Ethical review and approval were waived even considering that the type of this study is a literature review.

Informed Consent Statement: Not applicable.

Data Availability Statement: Not applicable.

Conflicts of Interest: The authors have no conflicts of interest to declare on the present study.

\section{References}

1. Wojciechowski, W.; Harris, D.P.; Sprague, F.; Mousseau, B.; Makris, M.; Kusser, K.; Honjo, T.; Mohrs, K.; Mohrs, M.; Randall, T.; et al. Cytokine-producing effector B cells regulate type 2 immunity to H. polygyrus. Immunity 2009, 30, 421-433. [CrossRef]

2. Hoffman, W.; Lakkis, F.G.; Chalasani, G. B Cells, Antibodies, and More. Clin. J. Am. Soc. Nephrol. 2016, 11, 137-154. [CrossRef] [PubMed] 
3. Beck, L.H.; Bonegio, R.G.B.; Lambeau, G. M-type phospholipase A2 receptor as target antigen in primary membranous nephropathy. N. Engl. J. Med. 2009, 361, 11-21. [CrossRef] [PubMed]

4. Hofstra, J.M.; Beck, L.H.; Beck, D.M. Anti-phospholipase A2receptor antibodies correlate with clinical status in primary membranous nephropathy. Clin. J. Am. Soc. Nephrol. 2011, 6, 1286-1291. [CrossRef] [PubMed]

5. Hoxha, E.; Thiele, I.; Zahner, G. Phospholipase A2 receptor autoantibodies and clinical outcome in patients with primary membranous nephropathy. J. Am. Soc. Nephrol. 2014, 25, 1357-1366. [CrossRef]

6. Tomas, N.M.; Beck, L.H.; Meyer-Schwesinger, C. Thrombospondin type-1 domain-containing 7A in idiopathic membranous nephropathy. N. Engl. J. Med. 2014, 371, 2277-2287. [CrossRef]

7. Ronco, P.; Debiec, H. Membranous nephropathy: Current understanding of various causes in light of new target antigens. Curr. Opin. Nephrol. Hypertens. 2021, 30, 287-293. [CrossRef] [PubMed]

8. Ghiggeri, G.M.; Seitz-Polski, B.; Justino, J.; Zaghrini, C.; Payré, C.; Brglez, V.; Dolla, G.; Sinico, A.; Scolari, F.; Vaglio, A.; et al. Multi-autoantibody signature and clinical outcome in membranous nephropathy. Clin. J. Am. Soc. Nephrol. 2020, 15, $1762-1776$. [CrossRef]

9. Maas, R.J.; Deegens, J.K.; Smeets, B.; Moeller, M.J.; Wetzels, J.F. Minimal change disease and idiopathic FSGS: Manifestations of the same disease. Nat. Rev. Nephrol. 2016, 12, 768-776. [CrossRef]

10. Podestà, M.A.; Ponticelli, C. Autoimmunity in focal segmental glomerulosclerosis: A long-standing yet elusive association. Front. Med. 2020, 7, 604-961. [CrossRef]

11. Gauckler, P.; Shin, J.; Alberici, F.; Audard, V.; Bruchfeld, A.; Busch, M.; Cheung, C.K.; Crnogorac, M.; Delbarba, E.; Eller, K.; et al. Rituximab in adult minimal change disease and focal segmental glomerulosclerosis-What is known and what is still unknown? Autoimmun. Rev. 2020, 19, 102671. [CrossRef] [PubMed]

12. Ejaz, A.A.; Asmar, A.; Alsabbagh, M.M.; Ahsan, N. Rituximab in immunologic glomerular diseases. MAbs 2012, 4, $198-207$. [CrossRef] [PubMed]

13. Beers, S.A.; Chan, C.H.T.; French, R.R.; Cragg, M.S.; Glennie, M.J. CD20 as a target for therapeutic Type I and II monoclonal antibodies. Semin. Hematol. 2010, 47, 107-114. [CrossRef] [PubMed]

14. Brando, B.; Gatti, A.; Lurati, A.M.; Faggioli, P.M.L. Monitoring anti-B cell immunotherapies in autoimmune diseases: Go with the flow. A position paper of the Italian Society for Clinical Cell Analysis (ISCCA). Beyond Rheumatol. 2019, 1, 26. [CrossRef]

15. Sacco, K.A.; Abraham, R.S. Consequences of B-cell-depleting therapy: Hypogammaglobulinemia and impaired B-cell reconstitution. Immunotherapy 2018, 10, 713-728. [CrossRef] [PubMed]

16. Weiner, G.J. Rituximab: Mechanism of action. Semin. Hematol. 2010, 47, 115-123. [CrossRef]

17. Rougé, L.; Chiang, N.; Steffek, M.; Kugel, C.; Croll, T.I.; Tam, C.; Estevez, A.; Arthur, C.P.; Koth, C.M.; Ciferri, C.; et al. Structure of CD20 in complex with the therapeutic monoclonal antibody rituximab. Science 2020, 367, 1224-1230. [CrossRef]

18. Van der Kolk, L.E.; Grillo-Lopez, A.J.; Baars, J.W.; Hack, C.E.; van Oers, M.H. Complement activation plays a key role in the side-effects of rituximab treatment. Br. J. Haematol. 2001, 115, 807-811. [CrossRef]

19. Merkt, W.; Lorenz, H.M.; Watzl, C. Rituximab induces phenotypical and functional changes of NK cells in a non-malignant experimental setting. Arthritis Res. Ther. 2016, 18, 206. [CrossRef] [PubMed]

20. Tasaki, M.; Shimizu, A.; Hanekamp, I.; Torabi, R.; Villani, V.; Yamada, K. Rituximab treatment prevents the early development of proteinuria following pig-to-baboon xeno-kidney transplantation. J. Am. Soc. Nephrol. 2014, 25, 737-744. [CrossRef]

21. Fornoni, A.; Sageshima, J.; Wei, C.; Merscher-Gomez, S.; Aguillon-Prada, R.; Jauregui, A.N.; Li, J.; Mattiazzi, A.; Ciancio, G.; Chen, L.; et al. Rituximab targets podocytes in recurrent focal segmental glomerulosclerosis. Sci. Transl. Med. 2011, 3, 85ra46. [CrossRef] [PubMed]

22. Rovin, B.H.; Adler, S.G.; Barratt, J.; Bridoux, F.; Burdge, K.A.; Chan, T.M.; Floege, J. KDIGO 2021 Clinical Practice Guideline for the Management of Glomerular Diseases. Kidney Int. 2021, 100, S3-S276.

23. Dahan, K.; Debiec, H.; Plaisier, E.; Cachanado, M.; Rousseau, A.; Wakselman, L.; Michel, P.A.; Mihout, F.; Dussol, B.; Matignon, M.; et al. Rituximab for severe membranous nephropathy: A 6-month trial with extended follow-up. J. Am. Soc. Nephrol. 2017, 28, 348-358. [CrossRef]

24. Fervenza, F.C.; Appel, G.B.; Barbour, S.J.; Rovin, B.H.; Lafayette, R.A.; Aslam, N.; Jefferson, J.A.; Gipson, P.E.; Rizk, D.V.; Sedor, J.R.; et al. MENTOR Investigators. Rituximab or Cyclosporine in the Treatment of Membranous Nephropathy. N. Engl. J. Med. 2019, 381, 36-46. [CrossRef]

25. Ponticelli, C.; Passerini, P.; Del Vecchio, L.; Locatelli, F. The evolution of the therapeutic approach to membranous nephropathy. Nephrol. Dial. Transpl. 2021, 36, 768-773. [CrossRef]

26. Huang, L.; Dong, Q.R.; Zhao, Y.J.; Hu, G.C. Rituximab for the management of idiopathic membranous nephropathy: A metaanalysis. Int. Urol. Nephrol. 2021, 53, 111-119. [CrossRef]

27. Fernández-Juárez, G.; Rojas-Rivera, J.; Logt, A.V.; Justino, J.; Sevillano, A.; Caravaca-Fontán, F.; Ávila, A.; Rabasco, C.; Cabello, V.; Varela, A.; et al. The STARMEN trial indicates that alternating treatment with corticosteroids and cyclophosphamide is superior to sequential treatment with tacrolimus and rituximab in primary membranous nephropathy. Kidney Int. 2021, 99, $986-998$. [CrossRef] [PubMed]

28. Scolari, F.; Delbarba, E.; Santoro, D.; Gesualdo, L.; Pani, A.; Dallera, N.; Mani, L.Y.; Santostefano, M.; Feriozzi, S.; Quaglia, M.; et al. Rituximab or cyclophosphamide in the treatment of membranous nephropathy: The RI-CYCLO Randomized Trial. J. Am. Soc. Nephrol. 2021, 32, 972-982. [CrossRef] [PubMed] 
29. Fenoglio, R.; Baldovino, S.; Sciascia, S.; De Simone, E.; Del Vecchio, G.; Ferro, M.; Quattrocchio, G.; Naretto, C.; Roccatello, D. Efficacy of low or standard rituximab-based protocols and comparison to Ponticelli's regimen in membranous nephropathy. J. Nephrol. 2021, 34, 565-571. [CrossRef]

30. Ren, H.; Lin, L.; Shen, P.; Li, X.; Xie, J.; Pan, X.; Zhang, W.; Chen, N. Rituximab treatment in adults with refractory minimal change disease or focal segmental glomerulosclerosis. Oncotarget 2017, 8, 93438-93443. [CrossRef]

31. Cortazar, F.B.; Rosenthal, J.; Laliberte, K.; Niles, J.L. Continuous B-cell depletion in frequently relapsing, steroid-dependent and steroid-resistant nephrotic syndrome. Clin. Kidney. J. 2018, 12, 224-231. [CrossRef]

32. Kamei, K.; Ishikura, K.; Sako, M.; Ito, S.; Nozu, K.; Iijima, K. Rituximab therapy for refractory steroid-resistant nephrotic syndrome in children. Pediatric Nephrol. 2020, 35, 17-24. [CrossRef]

33. Allinovi, M.; Trivioli, G.; Lugli, G.; Villanti, M.; Gianassi, I.; Antognoli, G.; Romagnani, P.; Vaglio, A.; Caroti, L.; Cirami, C.L. Proteinuria selectivity index predicts response to rituximab in adults with minimal change disease and focal segmental glomerulosclerosis. Nephrol. Dial. Transpl. 2021, 12, gfab323. [CrossRef] [PubMed]

34. Ruggenenti, P.; Ruggiero, B.; Cravedi, P.; Vivarelli, M.; Massella, L.; Marasà, M.; Chianca, A.; Rubis, N.; Ene-Iordache, B.; Rudnicki, M.; et al. Rituximab in Nephrotic Syndrome of Steroid-Dependent or Frequently Relapsing Minimal Change Disease Or Focal Segmental Glomerulosclerosis (NEMO) Study Group. Rituximab in steroid-dependent or frequently relapsing idiopathic nephrotic syndrome. J. Am. Soc. Nephrol. 2014, 25, 850-863. [CrossRef] [PubMed]

35. Roccatello, D.; Sciascia, S.; Rossi, D.; Alpa, M.; Naretto, C.; Radin, M.; Barreca, A.; Fenoglio, R.; Baldovino, S.; Menegatti, E. High-dose rituximab ineffective for focal segmental glomerulosclerosis: A long-term observation study. Am. J. Nephrol. 2017, 46, 108-113. [CrossRef]

36. De Vriese, A.S.; Sethi, S.; Nath, K.A.; Glassock, R.J.; Fervenza, F.C. Differentiating primary, genetic, and secondary FSGS in adults: A clinicopathologic approach. J. Am. Soc. Nephrol. 2018, 29, 759-774. [CrossRef]

37. Hansrivijit, P.; Cheungpasitporn, W.; Thongprayoon, C.; Ghahramani, N. Rituximab therapy for focal segmental glomerulosclerosis and minimal change disease in adults: A systematic review and meta-analysis. BMC Nephrol. 2020, 21, 134. [CrossRef]

38. Iijima, K.; Sako, M.; Nozu, K.; Mori, R.; Tuchida, N.; Kamei, K.; Miura, K.; Aya, K.; Nakanishi, K.; Ohtomo, Y.; et al. Rituximab for childhood-onset, complicated, frequently relapsing nephrotic syndrome or steroid-dependent nephrotic syndrome: A multicentre, double-blind, randomised, placebo-controlled trial. Lancet 2014, 384, 1273-1281. [CrossRef]

39. Ravani, P.; Rossi, R.; Bonanni, A.; Quinn, R.R.; Sica, F.; Bodria, M.; Pasini, A.; Montini, G.; Edefonti, A.; Belingheri, M.; et al. Rituximab in Children with Steroid-Dependent Nephrotic Syndrome: A Multicenter, Open-Label, Noninferiority, Randomized Controlled Trial. J. Am. Soc. Nephrol. 2015, 26, 2259-2266. [CrossRef] [PubMed]

40. Ahn, Y.H.; Kim, S.H.; Han, K.H.; Choi, H.J.; Cho, H.; Lee, J.W.; Shin, J.I.; Cho, M.H.; Lee, J.H.; Park, Y.S.; et al. Efficacy and safety of rituximab in childhood-onset, difficult-to-treat nephrotic syndrome: A multicenter open-label trial in Korea. Medicine 2018, 97, e13157. [CrossRef] [PubMed]

41. Basu, B.; Sander, A.; Roy, B.; Preussler, S.; Barua, S.; Mahapatra, T.K.S.; Schaefer, F. Efficacy of Rituximab vs Tacrolimus in Pediatric Corticosteroid-Dependent Nephrotic Syndrome: A Randomized Clinical Trial. JAMA Pediatric 2018, 172, 757-764. [CrossRef] [PubMed]

42. Van de Logt, A.E.; Dahan, K.; Rousseau, A.; van der Molen, R.; Debiec, H.; Ronco, P.; Wetzels, J. Immunological remission in PLA2R-antibody-associated membranous nephropathy: Cyclophosphamide versus rituximab. Kidney Int. 2018, 93, $1016-1017$. [CrossRef]

43. Wang, X.; Cui, Z.; Zhang, Y.M.; Qu, Z.; Wang, F.; Meng, L.Q.; Cheng, X.Y.; Liu, G.; Zhou, F.D.; Zhao, M.H. Rituximab for non-responsive idiopathic membranous nephropathy in a Chinese cohort. Nephrol. Dial. Transpl. 2018, 33, 1558-1563. [CrossRef]

44. Pourcine, F.; Dahan, K.; Mihout, F.; Cachanado, M.; Brocheriou, I.; Debiec, A.; Ronco, P. Prognostic value of PLA2R autoimmunity detected by measurement of anti-PLA2R antibodies combined with detection of PLA2R antigen in membranous nephropathy: A single-centre study over 14 years. PLoS ONE 2017, 12, e0173201. [CrossRef] [PubMed]

45. Dahan, K.; Johannet, C.; Esteve, E.; Plaisier, E.; Debiec, H.; Ronco, P. Retreatment with rituximab for membranous nephropathy with persistently elevated titers of anti-phospholipase A2 receptor antibody. Kidney Int. 2019, 95, 233-234. [CrossRef]

46. Seitz-Polski, B.; Debiec, H.; Rousseau, A.; Dahan, K.; Zaghrini, C.; Payré, C.; Esnault, V.L.M.; Lambeau, G.; Ronco, P. Phospholipase A2 receptor 1 epitope spreading at baseline predicts reduced likelihood of remission of membranous nephropathy. J. Am. Soc. Nephrol. 2018, 29, 401-408. [CrossRef]

47. Brglez, V.; Boyer-Suavet, S.; Zorzi, K.; Fernandez, C.; Fontas, E.; Esnault, V.; Seitz-Polski, B. Personalized medicine for PLA2R1related membranous nephropathy: A multicenter randomized control trial. Front. Med. 2020, 7, 412. [CrossRef] [PubMed]

48. Boyer-Suavet, S.; Andreani, M.; Cremoni, M.; Brglez, V.; Benzaken, S.; Bernard, G.; Nachman, P.; Esnault, V.; Seitz-Polski, B. Rituximab bioavailability in primary membranous nephropathy. Nephrol. Dial. Transpl. 2019, 34, 1423-1425. [CrossRef] [PubMed]

49. Smith, G.C. Is there a role for rituximab in the treatment of idiopathic childhood nephrotic syndrome? Pediatric Nephrol. 2007, 22, 893-898. [CrossRef]

50. Fujimoto, K.; Kumano, Y.; Kagaya, S.; Fujii, A.; Tsuruyama, Y.; Matsuura, T.; Yamazaki, K.; Nomura, K.; Okada, K.; Okino, K.; et al. Retrospective single-arm cohort study of steroid-dependent minimal change nephrotic syndrome treated with very low-dose rituximab. Clin. Nephrol. 2021, 95, 29-36. [CrossRef]

51. Prytuła, A.; Ijjima, K.; Kamei, K.; Fujii, A.; Tsuruyama, Y.; Matsuura, T.; Yamazaki, K.; Nomura, K.; Okada, K.; Okino, K.; et al. Rituximab in refractory nephrotic syndrome. Pediatric Nephrol. 2010, 25, 461-468. [CrossRef] 
52. Chan, E.; Webb, H.; Yu, E.; Ghiggeri, G.M.; Kemper, M.J.; Lap-Tak Ma, A.; Yamamura, T.; Sinha, A.; Bagga, A.; Hogan, J.; et al. Both the rituximab dose and maintenance immunosuppression in steroid-dependent/frequently-relapsing nephrotic syndrome have important effects on outcomes. Kidney Int. 2020, 97, 393-401. [CrossRef] [PubMed]

53. Hogan, J.; Dossier, C.; Kwon, T.; Macher, M.A.; Maisin, A.; Couderc, A.; Niel, O.; Baudouin, V.; Deschênes, G. Effect of different rituximab regimens on $\mathrm{B}$ cell depletion and time to relapse in children with steroid-dependent nephrotic syndrome. Pediatric Nephrol. 2019, 34, 253-259. [CrossRef]

54. Maxted, A.; Dalrymple, R.; Chisholm, D.; McColl, J.; Tse, Y.; Christian, M.; Reynolds, B.C. Low-dose rituximab is no less effective for nephrotic syndrome measured by 12-month outcome. Pediatric Nephrol. 2019, 34, 855-863. [CrossRef]

55. Fervenza, F.C.; Abraham, R.S.; Erickson, S.B.; Irazabal, M.V.; Eirin, A.; Specks, U.; Nachman, P.H.; Bergstralh, E.J.; Leung, N.; Cosio, F.G.; et al. Rituximab therapy in idiopathic membranous nephropathy: A 2-year study. Clin. J. Am. Soc. Nephrol. 2010, 5, 2188-2198. [CrossRef]

56. Fogueri, U.; Cheungapasitporn, W.; Bourne, D.; Fervenza, F.C.; Joy, M.S. Rituximab exhibits altered pharmacokinetics in patients with membranous nephropathy. Ann. Pharmacother. 2019, 53, 357-363. [CrossRef] [PubMed]

57. Stahl, K.; Duong, M.; Schwarz, A.; Wagner, A.D.; Haller, H.; Schiffer, M.; Jacobs, R. Kinetics of rituximab excretion into urine and peritoneal fluid in two patients with nephrotic syndrome. Case Rep. Nephrol. 2017, 2017, 1372859. [CrossRef] [PubMed]

58. Jacobs, R.; Langer-Jacobus, T.; Stahl, K.; Haller, H.; Schmidt, R.E.; Schiffer, M. Detection and quantification of rituximab in the human urine. J. Immunol. Methods 2017, 451, 118-121. [CrossRef]

59. Counsilman, C.E.; Jol-van der Zijde, C.M.; Stevens, J.; Cransberg, K.; Bredius, R.G.; Sukhai, R.N. Pharmacokinetics of rituximab in a pediatric patient with therapy-resistant nephrotic syndrome. Pediatric Nephrol. 2015, 30, 1367-1370. [CrossRef]

60. Seitz-Polski, B.; Dahan, K.; Debiec, H.; Rousseau, A.; Andreani, M.; Zaghrini, C.; Ticchioni, M.; Rosenthal, A.; Benzaken, S.; Bernard, G.; et al. High-dose rituximab and early remission in PLA2R1-related membranous nephropathy. Clin. J. Am. Soc. Nephrol. 2019, 14, 1173-1182. [CrossRef]

61. Ellrichmann, G.; Bolz, J.; Peschke, M.; Duscha, A.; Hellwig, K.; Lee, D.H.; Linker, R.A.; Gold, R.; Haghikia, A. Peripheral CD19(+) B-cell counts and infusion intervals as a surrogate for long-term B-cell depleting therapy in multiple sclerosis and neuromyelitis optica/neuromyelitis optica spectrum disorders. J. Neurol. 2019, 266, 57-67. [CrossRef] [PubMed]

62. Mitchell, C.; Crayne, C.B.; Cron, R.P. Patterns of B Cell Repletion Following Rituximab Therapy in a Pediatric Rheumatology Cohort. ACR Open Rheumatol. 2019, 1, 527-532. [CrossRef]

63. Venhoff, N.; Niessen, L.; Kreuzaler, M.; Rolink, A.G.; Hässler, F.; Rizzi, M.; Voll, R.E.; Thiel, J. Reconstitution of the peripheral B lymphocyte compartment in patients with ANCA-associated vasculitides treated with rituximab for relapsing or refractory disease. Autoimmunity 2014, 47, 401-408. [CrossRef] [PubMed]

64. Trouvin, A.P.; Jacquot, S.; Grigioni, S.; Curis, E.; Dedreux, I.; Roucheux, E.; Boulard, H.; Vittecoq, O.; Le Loët, X.; Boyer, O.; et al. Usefulness of monitoring of $\mathrm{B}$ cell depletion in rituximab-treated rheumatoid arthritis patients in order to predict clinical relapse: A prospective observational study. Clin. Exp. Immunol. 2015, 180, 11-18. [CrossRef] [PubMed]

65. Reddy, V.R.; Pepper, R.J.; Shah, K.; Cambridge, G.; Henderson, S.R.; Klein, C.; Kell, L.; Taylor, S.J.; Isenberg, D.A.; Cragg, M.S.; et al. Disparity in Peripheral and Renal B-cell Depletion with Rituximab in Systemic Lupus Erythematosus: An Opportunity for Obinutuzumab? Rheumatology 2021. ahead of print.

66. Kemper, M.; Gellermann, J.; Habbig, S.; Krmar, R.T.; Dittrich, K.; Jungraithmayr, T.; Pape, L.; Patzer, L.; Billing, H.; Weber, L.; et al. Long-term follow-up after rituximab for steroid-dependent idiopathic nephrotic syndrome. Nephrol. Dial. Transpl. 2012, 27, 1910-1915. [CrossRef] [PubMed]

67. Ravani, P.; Magnasco, A.; Edefonti, A.; Murer, L.; Ghio, L.; Belingheri, M.; Benetti, E.; Murtas, C.; Messina, G.; Massella, L.; et al. Short-term effects of rituximab in children with steroid- and calcineurin-dependent nephrotic syndrome: A randomized controlled trial. Clin. J. Am. Soc. Nephrol. 2011, 6, 1308-1315. [CrossRef]

68. Cravedi, P.; Ruggenenti, P.; Sghirlanzoni, M.C.; Remuzzi, G. Titrating rituximab to circulating B cells to optimize lymphocytolytic therapy in idiopathic membranous nephropathy. Clin. J. Am. Soc. Nephrol. 2007, 2, 932-937. [CrossRef]

69. Ramachandran, R.; Bharati, J.; Rao, I.; Kashif, A.W.; Nada, R.; Minz, R.; Gupta, K.L.; Kohli, H.S. Persistent CD-19 depletion by rituximab is cost-effective in maintaining remission in calcineurin-inhibitor dependent podocytopathy. Nephrology 2019, 24, 1241-1247. [CrossRef]

70. Kamei, K.; Ito, S.; Nozu, K.; Iijima, K. Single dose of rituximab for refractory steroid-dependent nephrotic syndrome in children. Pediatric Nephrol. 2009, 24, 1321-1328. [CrossRef]

71. Fujinaga, S.; Hirano, D.; Nishizaki, N.; Kamei, K.; Ito, S.; Ohtomo, Y.; Shimizu, T.; Kaneko, K. Single infusion of rituximab for persistent steroid-dependent minimal-change nephrotic syndrome after long-term cyclosporine. Pediatric Nephrol. 2010, 25, 539-544. [CrossRef] [PubMed]

72. Sellier-Leclerc, A.L.; Baudouin, V.; Kwon, T.; Macher, M.A.; Guérin, V.; Lapillonne, H.; Deschênes, G.; Ulinski, T. Rituximab in steroid-dependent idiopathic nephrotic syndrome in childhood-follow-up after CD19 recovery. Nephrol. Dial. Transpl. 2012, 27, 1083-1089. [CrossRef] [PubMed]

73. Ramachandran, R.; Nayak, S.; Kumar, V.; Sethi, J.; Minz, R.; Kumar, V.; Rathi, M.; Kohli, H.S. Rituximab in primary membranous nephropathy: A comparative study of three dosing regimens. Nephrol. Dial. Transpl. 2021. ahead of print. [CrossRef]

74. Ramachandran, R.; Bharati, J.; Nada, R.; Minz, R.; Kohli, H.S. Rituximab in maintaining remission in adults with podocytopathy. Nephrology 2020, 25, 616-624. [CrossRef] 
75. Fernandez-Fresnedo, G.; Segarra, A.; Alexandru, S.; Delgado, R.; Ramos, N.; Egido, J.; Praga, M.; Trabajo de Enfermedades Glomerulares de la Sociedad Española de Nefrología (GLOSEN). Rituximab treatment of adult patients with steroid-resistant focal segmental glomerulosclerosis. Clin. J. Am. Soc. Nephrol. 2009, 4, 1317-1323. [CrossRef]

76. Ruggenenti, P.; Chiurchiu, C.; Abbate, M.; Perna, A.; Cravedi, P.; Bontempelli, M.; Remuzzi, G. Rituximab for idiopathic membranous nephropathy: Who can benefit? Clin. J. Am. Soc. Nephrol. 2006, 1, 738-748. [CrossRef] [PubMed]

77. Ruggenenti, P.; Debiec, H.; Ruggiero, B.; Chianca, A.; Pellé, T.; Gaspari, F.; Suardi, F.; Gagliardini, E.; Orisio, S.; Benigni, A.; et al. Anti-phospholipase A2 receptor antibody titer predicts post-rituximab outcome of membranous nephropathy. J. Am. Soc. Nephrol. 2015, 26, 2545-2558. [CrossRef] [PubMed]

78. Sinha, A.; Bhatia, D.; Gulati, A.; Rawat, M.; Dinda, A.K.; Hari, P.; Bagga, A. Efficacy and safety of rituximab in children with difficult-to-treat nephrotic syndrome. Nephrol. Dial. Transpl. 2015, 30, 96-106. [CrossRef]

79. Colucci, M.; Carsetti, R.; Cascioli, S.; Casiraghi, F.; Perna, A.; Ravà, L.; Ruggiero, B.; Emma, F.; Vivarelli, M. B Cell Reconstitution after Rituximab Treatment in Idiopathic Nephrotic Syndrome. J. Am. Soc. Nephrol. 2016, 27, 1811-1822. [CrossRef]

80. Sato, M.; Kamei, K.; Ogura, M.; Ishikura, K.; Ito, S. Relapse of nephrotic syndrome during post-rituximab peripheral blood B-lymphocyte depletion. Clin. Exp. Nephrol. 2018, 22, 110-116. [CrossRef] [PubMed]

81. Takahashi, T.; Okamoto, T.; Sato, Y.; Yamazaki, T.; Hayashi, A.; Aoyagi, H.; Ueno, M.; Kobayashi, N.; Uetake, K.; Nakanishi, M.; et al. Periodically repeated rituximab administrations in children with refractory nephrotic syndrome: 2-year multicenter observational study. Pediatric Nephrol. 2019, 34, 87-96. [CrossRef]

82. Fenoglio, R.; Sciascia, S.; Beltrame, G.; Mesiano, P.; Ferro, M.; Quattrocchio, G.; Menegatti, E.; Roccatello, D. Rituximab as a front-line therapy for adult-onset minimal change disease with nephrotic syndrome. Oncotarget 2018, 9, 28799-28804. [CrossRef] [PubMed]

83. Katsuno, T.; Masuda, T.; Saito, S.; Kato, N.; Ishimoto, T.; Kato, S.; Kosugi, T.; Tsuboi, N.; Kitamura, H.; Tsuzuki, T.; et al. Therapeutic efficacy of rituximab for the management of adult-onset steroid-dependent nephrotic syndrome: A retrospective study. Clin. Exp. Nephrol. 2019, 23, 207-214. [CrossRef]

84. Hiepe, F.; Dörner, T.; Hauser, A.E.; Hoyer, B.F.; Mei, H.; Radbruch, A. Long-lived autoreactive plasma cells drive persistent autoimmune inflammation. Nat. Rev. Rheumatol. 2011, 7, 170-178. [CrossRef]

85. Dass, S.; Rawstron, A.C.; Vital, E.M.; Henshaw, K.; McGonagle, D.; Emery, P. Highly sensitive B cell analysis predicts response to rituximab therapy in rheumatoid arthritis. Arthritis Rheum. 2008, 58, 2993-2999. [CrossRef] [PubMed]

86. Gatti, A.; Buccisano, F.; Scupoli, M.T.; Brando, B. The ISCCA flow protocol for the monitoring of anti-CD20 therapies in autoimmune disorders. Cytom. B Clin. Cytom. 2021, 100, 194-205. [CrossRef]

87. Sentís, A.; Diekmann, F.; Llobell, A.; de Moner, N.; Espinosa, G.; Yagüe, J.; Campistol, J.M.; Mirapeix, E.; Juan, M. Kinetic analysis of changes in T- and B-lymphocytes after anti-CD20treatment in renal pathology. Immunobiology 2017, 222, 620-630. [CrossRef] [PubMed]

88. Rosenzwajg, M.; Languille, E.; Debiec, H.; Hygino, J.; Dahan, K.; Simon, T.; Klatzmann, D.; Ronco, P. B- and T-cell subpopulations in patients with severe idiopathic membranous nephropathy may predict an early response to rituximab. Kidney Int. 2017, 92, 227-237. [CrossRef] [PubMed]

89. Iijima, K.; Sako, M.; Nozu, K. Rituximab for nephrotic syndrome in children. Clin. Exp. Nephrol. 2017, 21, 193-202. [CrossRef] [PubMed]

90. Leibler, C.; Moktefi, A.; Matignon, M.; Debiais-Delpech, C.; Oniszczuk, J.; Sahali, D.; Cohen, J.L.; Grimbert, P.; Audard, V. Rituximab and fibrillary glomerulonephritis: Interest of B cell reconstitution monitoring. J. Clin. Med. 2018, 7, 430. [CrossRef]

91. Pozdzik, A.; Beukinga, I.; Gu-Trantien, C.; Willard-Gallo, K.; Nortier, J.; Pradier, O. Circulating (CD3(-)CD19(+)CD20(-)IgD()CD27(high)CD38(high)) plasmablasts: Promising cellular biomarker for immune activity for anti-PLA2R1 related membranous nephropathy? Mediat. Inflamm. 2016, 2016, 7651024. [CrossRef]

92. Cambridge, G.; Leandro, M.J.; Lauren, J.; Fairhead, T.; Robinson, W.H.; Sokolove, J. B cell depletion with rituximab in patients with rheumatoid arthritis: Multiplex bead array reveals the kinetics of IgG and IgA antibodies to citrullinated antigens. J. Autoimmun. 2016, 70, 22-30. [CrossRef]

93. Reddy, V.; Klein, C.; Isenberg, D.A.; Glennie, M.J.; Cambridge, G.; Cragg, M.S.; Leandro, M.J. Obinutuzumab induces superior B-cell cytotoxicity to rituximab in rheumatoid arthritis and systemic lupus erythematosus patient samples. Rheumatology 2017, 56, 1227-1237. [CrossRef]

94. Cartron, G.; Watier, H. Obinutuzumab: What is there to learn from clinical trials? Blood 2017, 130, 581-589. [CrossRef]

95. Basu, B. Ofatumumab for rituximab-resistant nephrotic syndrome. N. Engl. J. Med. 2014, 370, 1268-1270. [CrossRef]

96. Podestà, M.A.; Gennarini, A.; Portalupi, V.; Rota, S.; Alessio, M.G.; Remuzzi, G.; Ruggenenti, P. Accelerating the depletion of circulating anti-phospholipase A2 receptor antibodies in patients with severe membranous nephropathy: Preliminary findings with double filtration plasmapheresis and ofatumumab. Nephron 2020, 144, 30-35. [CrossRef]

97. Ravani, P.; Colucci, M.; Bruschi, M.; Vivarelli, M.; Cioni, M.; DiDonato, A.; Cravedi, P.; Lugani, F.; Antonini, F.; Prunotto, M.; et al. Human or Chimeric Monoclonal Anti-CD20 Antibodies for Children with Nephrotic Syndrome: A Superiority Randomized Trial. J. Am. Soc. Nephrol. 2021, 32, 2652-2663. [CrossRef]

98. Jain, P.; Kanagal-Shamanna, R.; Wierda, W.; Ferrajoli, A.; Keating, M.; Jain, N. Membranoproliferative glomerulonephritis and acute renal failure in a patient with chronic lymphocytic leukemia: Response to obinutuzumab. Hematol. Oncol. Stem. Cell Ther. 2017, 10, 151-154. [CrossRef] [PubMed] 
99. Klomjit, N.; Fervenza, F.C.; Zand, L. Successful treatment of patients with refractory PLA2R-associated membranous nephropathy with obinutuzumab: A report of 3 cases. Am. J. Kidney Dis. 2020, 76, 883-888. [CrossRef] [PubMed]

100. Mulero, P.; Midaglia, L.; Montalban, X. Ocrelizumab: A new milestone in multiple sclerosis therapy. Ther. Adv. Neurol. Disord. 2018, 11, 1756286418773025. [CrossRef] [PubMed]

101. Schmidt, T.; Schulze, M.; Harendza, S.; Hoxha, E. Successful treatment of PLA 2 R1-antibody positive membranous nephropathy with ocrelizumab. J. Nephrol. 2021, 34, 603-606. [CrossRef]

102. Crickx, E.; Chappert, P.; Sokal, A.; Weller, S.; Azzaoui, I.; Vandenberghe, A.; Bonnard, G.; Rossi, G.; Fadeev, T.; Storck, S.; et al. Rituximab-resistant splenic memory B cells and newly engaged naive B cells fuel relapses in patients with immune thrombocytopenia. Sci. Transl. Med. 2021, 13, eabc3961. [CrossRef] [PubMed]

103. Stewart, A.; Ng, J.C.; Wallis, G.; Tsioligka, V.; Fraternali, F.; Dunn-Walters, D.K. Single-cell transcriptomic analyses define distinct peripheral b cell subsets and discrete development pathways. Front. Immunol. 2021, 12, 602539. [CrossRef] [PubMed]

104. Nissimov, N.; Hajiyeva, Z.; Torke, S.; Grondey, K.; Brück, W.; Häusser-Kinzel, S.; Weber, M.S. B cells reappear less mature and more activated after their anti-CD20-mediated depletion in multiple sclerosis. Proc. Natl. Acad. Sci. USA 2020, 117, 25690-25699. [CrossRef] [PubMed] 